- Note-

\title{
High Temperature Corrosion of Type 316 L Stainless Steel with Molten Carbonate. The Effect of Alkaline Earth Carbonate Addition
}

\author{
Masahiro YANAGIDA*, Sumihiko BABA ${ }^{\dagger \dagger}$, Kazumi TANIMOTO, Toshikatsu KoJIMA, \\ Norikazu OHTORI ${ }^{\dagger}$, Yukiko TAMIYA, Takashi ASAI, Yoshinori MIYAZAKI \\ and Masashi AZUMA ${ }^{\dagger \dagger}$
}

Received January 16, 1996 ; Accepted March 13, 1996

\section{INTRODUCTION}

The molten carbonate fuel cell (MCFC) is expected to be a high efficiency power generation device with low pollutant emission. Molten carbonate used as its electrolyte, which composition is conventionally $\mathrm{Li}_{2} \mathrm{CO}_{3}: \mathrm{K}_{2} \mathrm{CO}_{3}=62: 38((\mathrm{~mol} \%)$, separates anode and cathode gas environment and provides ionic conductivity under the MCFC operation. Some properties (e.g. melting point, conductivity, surface tension, corrosivity, etc.) of the carbonate as the electrolyte affect the performance and/or lifetime of the MCFC. That is, it causes some problems such as $\mathrm{NiO}$ cathode dissolution and corrosion of component materials. In MCFC technology, corrosion of materials is one of the life-limiting problems, since corrosion in the MCFC proceeds continuously with consumption of electrolyte as well as cell materials at the same time. Especially, the separator plates in an MCFC stack are exposed to the most severe conditions, since they are contact with molten carbonate as well as both oxidizing and reducing conditions and must retain adequate electronic conductivity.

Recently, the addition of the alkaline earth carbonates into $\left(\mathrm{Li}_{0.62} \mathrm{~K}_{0.38}\right)_{2} \mathrm{CO}_{3}$ has been reported to be effective to reduce the $\mathrm{NiO}$ solubility into the melt under cathode environment ${ }^{1}$. The addition will be expected, necessarily, to affect the other properties of $\left(\mathrm{Li}_{0.62} \mathrm{~K}_{0.38}\right)_{2} \mathrm{CO}_{3}$. Few reports were, however, known about the effect of

Osaka National Research Institute (1-8-31, Midorigaoka, Ikeda, Osaka 563, Japan)

+ Present address: Niigata University (Ikarashi 2-no cho, Niigata 950-

21, Japan)

t† Osaka Institute of Technology (5-16-1, Ohmiya, Asahi-ku, Osaka 535, Japan)

Key Words : High Temperature Corrosion, Molten Carbonate Fuel Cell, Stainless Steel, Alkaline Earth Carbonate the additions on corrosion of the MCFC components ${ }^{21}$.

This paper reports the effect of addition of alkaline earth carbonate in $\left(\mathrm{Li}_{0.62} \mathrm{~K}_{0.38}\right)_{2} \mathrm{CO}_{3}$ on corrosion rate and corrosion products of type $316 \mathrm{~L}$ stainless steel under the cathode environment in out-of-cell test.

\section{EXPERIMENTAL}

A sheet of commercially available type $316 \mathrm{~L}$ stainless steel (SS 316L), of thickness $0.5 \mathrm{~mm}$, served as corrosion specimen. Its chemical composition is listed in Table 1. The sheet was cut into $10 \times 20 \mathrm{~mm}$ specimens, polished with wet abrasive paper up to $\# 1000$, washed and decreased with acetone, and dried. Chemical reagent grade $\mathrm{Li}_{2} \mathrm{CO}_{3}, \mathrm{~K}_{2} \mathrm{CO}_{3}, \mathrm{CaCO}_{3}, \mathrm{SrCO}_{3}$ and $\mathrm{BaCO}_{3}$, which purity were $>99.0 \%,>99.5 \%,>99.99 \%,>99.9 \%$ and $>99.9 \%$, respectively, served for preparation of mixed carbonates. After these carbonates were dried for 12 hours at $523 \mathrm{~K}$ in the air, they were mixed as $\mathrm{Li}_{2} \mathrm{CO}_{3}: \mathrm{K}_{2} \mathrm{CO}_{3}=62: 38(\mathrm{~mol} \%)$ and $\left(\mathrm{Li}_{0.62} \mathrm{~K}_{0.38}\right)_{2} \mathrm{CO}_{3}$ $:\left(\mathrm{CaCO}_{3}, \mathrm{SrCO}_{3}\right.$ or $\left.\mathrm{BaCO}_{3}\right)=90: 10(\mathrm{~mol} \%)$. From now on they are referred to as $\mathrm{Li} / \mathrm{K}, \mathrm{Li} / \mathrm{K} / \mathrm{Ca}, \mathrm{Li} / \mathrm{K} / \mathrm{Sr}$ and $\mathrm{Li} /$ $\mathrm{K} / \mathrm{Ba}$, respectively. Each mixed carbonate was previously melted at $923 \mathrm{~K}$ under $\mathrm{CO}_{2}$ atmosphere in high purity alumina crucible $\left(\mathrm{Al}_{2} \mathrm{O}_{3}>99.5 \%\right)$, quenched and ground. The compositions of the carbonates were confirmed after melt by inductively coupled plasma atomic emission spectroscopy (ICP-AES). Specimens were coated with $5 \mathrm{mg} / \mathrm{cm}^{2}$ carbonate with ethanol and hung in alumina crucible. Specimens in the crucible were set in the furnace for corrosion test. The out-of-cell corrosion test was carried out under the cathode environment

Table 1 Chemical composition in wt\% of SS $316 \mathrm{~L}$ used.

\begin{tabular}{ccccccccccc}
$\mathrm{C}$ & $\mathrm{P}$ & $\mathrm{S}$ & $\mathrm{O}$ & $\mathrm{N}$ & $\mathrm{Si}$ & $\mathrm{Mn}$ & $\mathrm{Mo}$ & $\mathrm{Ni}$ & $\mathrm{Cr}$ & $\mathrm{Fe}$ \\
\hline 0.022 & 0.0029 & 0.010 & 0.0060 & 0.0262 & 0.65 & 1.01 & 2.14 & 12.01 & 17.02 & Bal.
\end{tabular}


( $\mathrm{CO}_{2}: \mathrm{O}_{2}=67: 33$ (vol\%), $300 \mathrm{~cm}^{3} / \mathrm{min}$ flow) at $923 \mathrm{~K}$ for 100,200 and 500 hours.

After the test, the deposit of carbonate melt was observed to remain on the specimen. Each specimen was washed in distilled water to remove the carbonate. The solution was analyzed quantitatively by ICP-AES to examine the elements which dissolved from the specimen into the carbonate. Weight change due to corrosion is calculated by weighing the specimen before and after the test without carbonate. The surface and cross section of each specimen were observed by SEM and analyzed by energy dispersive electron probe microanalysis (EPMA). Corrosion products on the each specimen before and after removal of carbonate were identified by X-ray diffraction (XRD) with a fixed incident angle.

\section{RESULTS AND DISCUSSION}

Results of weight gains of the specimens with time are shown in Fig. 1. Though $\mathrm{Cr}$ was only detected in all the melts after the test as the element dissolved from the specimen using ICP-AES analysis, the analysis showed the weight changes due to the dissolution of $\mathrm{Cr}$ into melts were less than $0.3 \mathrm{mg}$, which were negligibly small. The weight of all the specimens increases with time. The weight gains with the addition of each alkaline earth carbonate are always less than those without the addition. It shows that the addition of $\mathrm{CaCO}_{3}, \mathrm{SrCO}_{3}$ or $\mathrm{BaCO}_{3}$ decreases the corrosion of SS $316 \mathrm{~L}$. No remarkable difference is, however, found among the weight gains due to the corrosion in all the additions. On the contrary, only minor differences in corrosion of SS $310 \mathrm{~S}$ between with the addition of $5 \mathrm{~mol} \% \mathrm{BaCO}_{3}$ and without the addition have been shown ${ }^{2)}$. Among various rate equations, all the weight gains with time always best fit the parabolic rate one:

$$
x^{2}=k_{\mathrm{p}} \cdot t
$$

where $x$ is the weight gain $(\mathrm{mg}), k_{\mathrm{p}}$ the parabolic rate constant $\left(\mathrm{mg}^{2} / \mathrm{h}\right)$, and $t$ the time exposed (h). Each $k_{\mathrm{p}}$ for corrosion of SS $316 \mathrm{~L}$ under ambient $67 \% \mathrm{CO}_{2}+33 \% \mathrm{O}_{3}$ at $923 \mathrm{~K}$ with the melts is calculated in Table 2 .

The surface observation using SEM after the test showed that all the specimens were covered with the facet corrosion products and there was no significant difference of morphology among the corrosion products at the same duration with each composition of all the melts. The corrosion products for $\mathrm{L} / \mathrm{K}$ were identified as $\mathrm{LiFeO}_{2}, \mathrm{LiFe}_{5} \mathrm{O}_{8}$ and $\mathrm{LiCrO}_{2}$ by XRD and were similar to those for $\mathrm{Li} / \mathrm{K} / \mathrm{Ca}, \mathrm{Li} / \mathrm{K} / \mathrm{Sr}$ and $\mathrm{Li} / \mathrm{K} / \mathrm{Ba}$. NoCa, Sr or

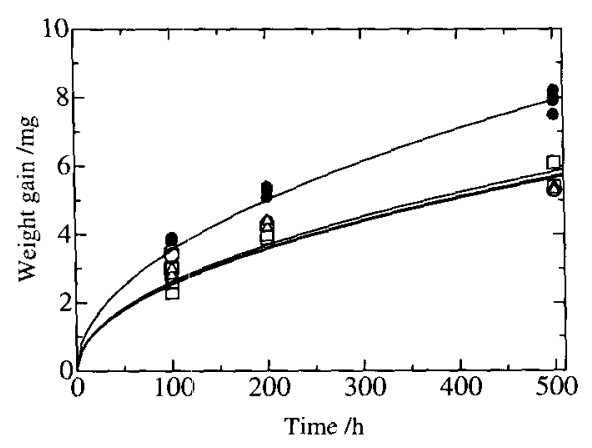

Fig. 1 Weight gain as a function of time for SS $316 \mathrm{~L}$ specimens coated with different carbonate deposits $\left(5 \mathrm{mg} / \mathrm{cm}^{2}\right)$ reacted at $923 \mathrm{~K}$ in $67 \% \mathrm{CO}_{2}+33 \% \mathrm{O}_{2}$.

$\mathrm{Li} / \mathrm{K}(\bigcirc), \mathrm{Li} / \mathrm{K} / \mathrm{Ca}(\bigcirc), \mathrm{Li} / \mathrm{K} / \mathrm{Sr}(\square), \mathrm{Li} / \mathrm{K} / \mathrm{Ba}(\triangle)$ ), calculated according to the parabolic rate equation (-).

Table 2 Parabolic rate constants for corrosion of SS $316 \mathrm{~L}$ under ambient $67 \% \mathrm{CO}_{2}+33 \% \mathrm{O}_{2}$ at $923 \mathrm{~K}$ with various carbonate deposits $\left(5 \mathrm{mg} / \mathrm{cm}^{2}\right)$.

\begin{tabular}{cc}
$\begin{array}{c}\text { Composition of carbonates } \\
(\mathrm{mol} \%)\end{array}$ & \multicolumn{1}{c}{$\begin{array}{c}\text { Parabolic rate constant, } k_{\mathrm{p}} \\
\left(\mathrm{mg}^{2} / \mathrm{h}\right)\end{array}$} \\
\hline $\mathrm{Li}_{2} \mathrm{CO}_{3}: \mathrm{K}_{2} \mathrm{CO}_{3}=62: 38$ & $1.3 \times 10^{-1}$ \\
$\left(\mathrm{Li}_{0.6 .2} \mathrm{~K}_{0.38}\right)_{2} \mathrm{CO}_{3}: \mathrm{CaCO}_{3}=90: 10$ & $6.5 \times 10^{-2}$ \\
$\left(\mathrm{Li}_{0.62} \mathrm{~K}_{6.38}\right)_{2} \mathrm{CO}_{3}: \mathrm{SrCO}_{3}=90: 10$ & $6.8 \times 10^{-2}$ \\
$\left(\mathrm{Li}_{0.62} \mathrm{~K}_{0.38}\right)_{2} \mathrm{CO}_{3}: \mathrm{BrCO}_{3}=90: 10$ & $6.4 \times 10^{-2}$ \\
\hline
\end{tabular}

Ba compound was found in the corrosion products for $\mathrm{Li} / \mathrm{K} / \mathrm{Ca}, \mathrm{Li} / \mathrm{K} / \mathrm{Sr}$ or $\mathrm{Li} / \mathrm{K} / \mathrm{Ba}$

The EPMA results showed that the structure of corrosion products consisted of two layers. The inner and outer layers were identified as $\mathrm{LiFeO}_{2}$ and $\mathrm{LiFe}_{5} \mathrm{O}_{8}$, and $\mathrm{LiCrO}_{2}$, respectively, in all the melt systems.

No dependence of corrosion products on the carbonate compositions suggested that the change of the melt properties such as activity of oxidizing species and solubility of gases depending on the addition would rather play important roles in the corrosion mechanism. The addition effect on the melt properties of the Li-K carbonate system should be elucidated to understand the corrosion behavior furthermore.

\section{References}

1) K. Tanimoto, Y. Miyazaki, M. Yanagida, S. Tanase, T. Kojima, N. Ohtori, H. Okuyama and T. Kodama, Denki Kagaku, 59, 619 (1991).

2) C. Y. Yuh and A. Pigeaud, U.S. DOE Report DE900900410, June (1989). 